\title{
Genetic Analysis of Agronomic Traits in Bread Wheat Using Six Parameters Model under Heat Stress
}

\section{K. A. Hamam}

Agronomy Department, Faculty of Agriculture, Sohag University, Sohag, Egypt.

NHERITANCE of yield and yield contributing characters were
investigated using generation mean analysis, utilizing the means of
six populations in parents, F1, F2 and backcross generations of three
crosses of bread wheat using six parameters model under favorable
and heat stress conditions. This study was carried out during the three
successive seasons of $2009 / 2010,2010 / 2011$ and $2011 / 2012$ at the
Experimental Farm of Faculty of Agriculture, Sohag University,
Egypt. The objective of this study was to determine nature of gene
action controlling yield and its components. Additive (d) and additive
x additive were highly significant and positive for most traits in all the
three crosses under favorable sown and heat stress, suggesting the
possibility of obtaining further improvements of these traits using a
pedigree selection method. Dominance and dominance x dominance
gene actions were also found, though the significance and direction
was specific for each environment and genotypic cross, indicating the
importance of dominance gene effects. Heritability estimates in
narrow sense in $\mathrm{F}_{2}$ were relatively high to moderate more than
$34.26 \%$ and $42.22 \%$ under favorable and heat stress, respectively. The
promising crosses were the first cross (Giza164 x Qimma 4 ) and third
cross (Gemmeiza 9 x Johara14), were found to high in magnitude
which had high genetic advance associated with high heritability and
would be interest in breeding programs for heat tolerance.

Keywords: Wheat, Gene action, Gene effects, Epistasis, Additive, Dominance, Heritability, Six parameters model, Heat stress.

Wheat (Triticum aestivum L.) was considered as important cereal crop not only in Egypt but also all over world. There was an increasing demand in wheatworld wide. The annual world production of wheat amounts to $670,875,110$ tones. After maize and rice, wheat ranks as the third most important crop in the world (FAO, 2012). In the world, there was an urgent need to increase the productivity of wheat to reduce the food gap resulting from population increase.

Generation mean analysis, which provide the estimates of main gene effects (additive and dominance) along with their digenic interactions (additive $\mathrm{x}$ additive, additive $\mathrm{x}$ dominance and dominance $\mathrm{x}$ dominance) helps in understanding the nature of gene effects involved in different traits concern and 
accordingly the breeding procedure could be applied in developing superior populations. The study of the genotype by environment interaction and the estimation of genetic parameters were needed, once it provides information about the nature of genes involved in the inheritance of traits under investigation and help in choosing the most satisfactory breeding method, what helps breeders to make decisions. Bayoumi et al. (2008) found that additive dominance model were adequate for revealing the inheritance of grain yield and its components. Yap (1993) studied the inheritance pattern of long bean through diallel cross, which does not provide the estimates of different non-allelic gene interactions operating in the inheritance. Epistasis, which was known to play an important role in the expression of heterotic potential, has been demonstrated by Rebetzke et al. (2003). Sharma et al. (2003), indicated that both additive and non-additive gene effects were predominant for most studied traits, though the non-additive gene effects were also important.

The Upper Egypt region presents an inconvenient high temperatures occurrence during the wheat cycle special. Heat stress, due to increased temperature, was an agricultural problem in many areas in the world (Wahid et al., 2007). Many studies have confirmed the damaging effect of heat on wheat (Rane \& Nagarajan, 2004 and Cargnin et al., 2006), as well as the presence of genotype by environment interaction under contrasting temperature conditions (Cargnin et al., 2006), Haj et al. (2007), El-Marakby et al. (2007) and Khan et al. (2007) found reduction of days to heading, plant height, no. of spikes $/ \mathrm{m}^{2}$, no. of kernels/spike, 1000-kernel weight and final grain yield with delayed sowing date. The major yield components in wheat were tillers/plant, kernels/spike and 1000-kernel weight (Maloo et al., 1993). Hu \& Rajaram (1994) also reported that kernels/spike could be considered a potential selection criterion under late sown condition. High temperature has been used as a screening tool for predicting high wheat yield in rainfed environments (Olivares-Villegas et al., 2007). The potential of high temperature for screening wheat genotypes was based on its significant correlations with grain yield (Reynolds et al., 2001) and the genotype differences observed between cultivars (Araus et al., 2003).

The objectives of this study were to determine: i) The nature of gene action controlling yield and its component in three wheat crosses grown under favorable and heat stress conditions, ii) Estimate heterosis, inbreeding effect, potence ratio, broad and narrow sense heritability, genetic advance and as selection parameters in bread wheat.

\section{Material and Methods}

Six bread wheat cultivars representing a wide range of diversity were chosen as parents in this study under heat stress to obtain the following three crosses. Three of these cultivars were adapted and heat tolerant (Giza164, Giza168 and Gemmeiza 9) in Egypt. While the others were introduced (Qimma 4, Cham 6 and Johara14) from ICARDA-Syria. The parental genotypes were used to obtaine the following crosses; cross 1 (Giza164 x Qimma 4); cross 2 (Giza168 x Egypt. J. Agron . 36, No.1 (2014) 
Cham 6) and cross 3 (Gemmeiza 9 x Johara14). The present study was carried out at the experimental farm of Faculty of Agriculture, Sohag University, Sohag, Egypt during the three successive seasons 2009/2010 to 2011/2012. In the first season 2009/2010, the parental genotypes were crossed to obtain $\mathrm{F}_{1}$ kernels. In the second season 2010/2011, the hybrid kernels of the three crosses were sown to give $F_{1}$ plants, at the same time, these plants were selfed to produce $F_{2}$ and some of $F_{1}$ plants of each cross were backcrossed to each of the both parents to produce the backcrosses $\left(\mathrm{BC}_{1}\right.$ and $\left.\mathrm{BC}_{2}\right)$. In 2011/2012, the six populations $\left(\mathrm{P}_{1}\right.$, $\mathrm{P}_{2}, \mathrm{~F}_{1}, \mathrm{~F}_{2}, \mathrm{BC}_{1}$ and $\mathrm{BC}_{2}$ ) of the three crosses were sown in a randomized complete block design with three replications under two different sowing dates, favorable sown date as "Favorable", 15 November; (D1) and late sowing date as "Heat stress", 20 December; (D2) in two separate experiments (Table 1). Experimental unit consisted of four rows for each genotype of the two parents and F1 and five rows for each of the two backcrosses and 10 rows for the F2 population. Row was $3.5 \mathrm{~m}$ in length, $30 \mathrm{~cm}$ apart and $10 \mathrm{~cm}$ between kernels within a row. Data were recorded on 20, 20, 20 and 200 plants which were selected at random for both parents, F1, backcrosses and F2 of each cross, receptively. The type of soil in which the plants were grown surface layer of experiment soil was clay compared with subsurface layer which transported layer as results of reclamations.

TABLE 1. Maximum and minimum air temperatures $\left({ }^{\circ} \mathrm{C}\right)$ in Sohag during wheat growth stages in favorable (November) and heat stress conditions (December).

\begin{tabular}{|l|c|c|c|c|c|c|}
\hline \multirow{2}{*}{ Months } & \multicolumn{7}{|c|}{ 2009/2010 } & \multicolumn{2}{|c|}{ 2010/2011 } & \multicolumn{2}{c|}{ 2011/2012 } \\
\cline { 2 - 7 } & Max. & Min. & Max. & Min. & Max. & Min. \\
\hline November & 26.16 & 13.43 & 29.23 & 13.52 & 22.03 & 8.57 \\
\hline December & 22.54 & 8.67 & 24.41 & 10.18 & 21.37 & 7.55 \\
\hline January & 23.29 & 8.03 & 19.05 & 7.51 & 18.93 & 4.22 \\
\hline February & 26.51 & 8.03 & 27.64 & 9.42 & 20.81 & 7.09 \\
\hline March & 28.76 & 13.35 & 28.02 & 10.83 & 23.20 & 8.00 \\
\hline April & 33.81 & 12.00 & 33.49 & 20.53 & 31.58 & 15.75 \\
\hline May & 36.81 & 22.96 & 36.00 & 25.6 & 39.55 & 26.41 \\
\hline
\end{tabular}

\section{Statistical and genetic analysis}

Tests for scale effects were computed following the methods explained by Mather (1949) and Hayman \& Mather (1955). Estimation of different gene effects in the interacting crosses were done using six parameters (Hayman, 1958) and three parameters (Jinks \& Jones, 1958) models. The quantities A, B and C 
and their variances were calculated to test adequacy of the additive-dominance model in each case where: $A=2 \overline{B C} 1-\bar{P} 1-\bar{F} 1, B=2 \overline{B C} 2-\bar{P} 2-\bar{F} 1, C=4 \bar{F} 2-\bar{F} 1-\bar{P} 1-\bar{P} 2$. The variances of these estimates were calculated as follows:-

$V_{A}=4 V(\overline{B C} 1)+V(\bar{P} 1)+V(\bar{F} 1), V_{B}=4 V(\overline{B C} 2)+V(\bar{P} 2)+V(\bar{F} 1)$ and $V_{C}=16 V(\bar{F} 2)+4 V(\bar{F} 1)+V(\bar{P} 1)+V(\bar{P} 2)$, the standard error of A, B, C and D were obtained by taking the square root of their respective variance. T-test values were calculated by dividing the effects of $\mathrm{h}, \mathrm{d}, \mathrm{i}, \mathrm{j}$ and $\mathrm{L}$ on their respective standard errors. Generation means were analysed using the procedure of Gamble (1962) for estimation and separation of gene effects involved in the inheritance of yield and its component into six parameters. Hayman (1958) and Jinks \& Jones (1958) gave six-parameter model for estimations of various genetic components. According to Hayman (1958);

$m=$ Mean $=\bar{F} 2, d=$ Additiveeffect $=\overline{B C} 1-\overline{B C} 2$,

$h=$ Domin ance.effect $=\bar{F} 1-\bar{F} 2-0.5(\overline{P 1})-0.5(P 2)+2(\overline{B C} 1)+2(\overline{B C} 2)$

$i=$ Additive* Additivetype.of.gene.interaction $=2(\overline{B C})+2(\overline{B C} 2)-4 \bar{F} 2$

$j=$ Additive $^{*}$ Do min ance.type.of.gene.interaction $=\overline{B C} 1-0.5(\bar{P} 1)-(\overline{B C} 2)+0.5(\bar{P} 2)$

$L=$ Domin ance $*$ Domin ancetype.of.gene.interaction $=\bar{P} 1+\bar{P} 2+2 \bar{F} 1+4 \bar{F} 2-4(\overline{B C} 1)-4(\overline{B C} 2)$

The variance values in this concern were obtained as follows: $-V_{m}=V(\bar{F} 2)$,

$V_{d}=V(\overline{B C} 1)-V(\overline{B C} 2)$

$V_{h}=V(\bar{F} 1)-16 V(\bar{F} 2)-0.25 V(\overline{P 1})-0.25 V(P 2)+4 V(\overline{B C} 1)+4 V(\overline{B C} 2)$

$V_{i}=4 V(\overline{B C} 1)+4 V(\overline{B C} 2)-16 V(\bar{F} 2)$

$V_{j}=V(\overline{B C} 1)-0.25 V(\bar{P} 1)-V(\overline{B C} 2)+0.25 V(\bar{P} 2)$.

$V_{l}=V(\bar{P} 1)+V(\bar{P} 2)+4 V(\bar{F} 1)+16 V(\bar{F} 2)-16 V(\overline{B C} 1)-16 V(\overline{B C} 2)$.

The standard error of $\mathrm{h}, \mathrm{d}, \mathrm{i}, \mathrm{j}$ and $\mathrm{L}$ was obtained by taking the square root of their respective variance. The predicted genetic advance (GA) calculated using the procedure of Allard (1960) as follow: $(\mathrm{GA})=\mathrm{h}^{2} x(\sigma \mathrm{P}) x \mathrm{~K}$, where: $\sigma \mathrm{P}=$ standard deviation, $h^{2}=$ heritability in narrow sense, $\mathrm{K}=$ constant value that reflects the selection intensity. The value for $\mathrm{K}$ (2.06) in this study was used in $5 \%$ selection intensity. Heterosis was determined as the percent of the deviation of $\mathrm{F}_{1}$ hybrid from its better parent (BP) or its mid-parent (MP) values as this formula for better-parent $(\mathrm{BP})=\left[\left(\mathrm{F}_{1}-\right.\right.$ B.P. $) /$ B.P. X 100] where; $\mathrm{F}_{1}$ is the mean of $F_{1}$ hybrid. B.P. is the mean of the better parent. Or for mid-parent $(\mathrm{MP})=\left[\left(\mathrm{F}_{1}\right.\right.$ - M.P.)/ M.P. X 100] where; M.P. is the mean of the $\left(\mathrm{P}_{1}+\mathrm{P}_{2}\right) / 2$. Inbreeding depression was estimated as the average percentage decrease of the $F_{2}$ from the $\mathrm{F}_{1}$, potence ratio $(\mathrm{P})$ was also calculated according to Peter \& Frey (1966). Heritability in broad and narrow sense were estimated according to the formulae provided by Mather (1949).

Egypt. J. Agron . 36, No.1 (2014) 


\section{Results and Discussion}

\section{Mean performance}

Mean and standard error of the studied traits in the three crosses for six populations $\mathrm{P}_{1}, \mathrm{P}_{2}, \mathrm{~F}_{1}, \mathrm{~F}_{2}, \mathrm{BC}_{1}$ and $\mathrm{BC}_{2}$ under favorable and heat stress treatments presented in Table 2. Analysis of variance indicted that there were significant differences among generations in all traits under this study. The results revealed that generation means were significantly different for all studied traits in all crosses. The $\mathrm{F}_{1}$ mean values exceeded the mid values of the two parental means for most of studied traits in the three crosses under favorable sown and heat stress treatments, indicating the prevalence of heterotic effects and presence of dominance effects controlling these traits. For heading date the cross 3 was earlier than the mid parent indicating the presence of partial dominance. $F_{1}$ means were larger than the high performing parent for; 1000- kernel weight and grain yield/plant under favorable sown and heat treatments in all crosses, while for heading date the cross 1 , spike length in crosses 1 and 2, number of spikes/plant in crosses 1 and 3 and number of kernels/spike in crosses 1 and 2 under favorable sown and heat stress treatments indicating that increasing allels were more frequent than decreasing one under stress condition.

The $\mathrm{F}_{2}$ populations mean performance values were intermediate between the two parents and less than $\mathrm{F}_{1}$ mean performance values for all most traits confirming the importance of non-additive gene action for the studied traits. While, the mean performance of $\mathrm{F}_{2}$ population recorded high values for most studied traits under favorable sown. However, the two populations $\left(\mathrm{BC}_{1}\right.$ and $\mathrm{BC}_{2}$ ) mean performance values varied under the two levels of favorable sown and heat stress treatment and each trait tended toward the mean of its recurrent parent, reflecting the effect of epistasis. These results were in line with those obtained by Farag (2009) and Amin (2013).

\section{Estimation of type of gene action}

Scaling and joint scaling test

The values of $\mathrm{A}, \mathrm{B}$ and $\mathrm{C}$ should be equal zero within the limits of their standard error. The significant of any one of those scales was taken to indicate the presence of non- allelic interaction. Estimation of gene effects using six parameter model revealed the interaction components to be significant. Hence the six parameter model was employed to allow estimation of the additional parameters that were necessary to specify the effects of interaction of nonallelic genes. Testing for non- allelic interaction with the six parameter model and type of epistasis under favorable sown and heat stress treatments given in Table 3. The A, B and $\mathrm{C}$ scaling test almost all crosses and traits were found significant. However, the scaling test A some crosses for few traits like cross 1 for days to heading, crosses 1 and 3 for spike length and cross 3 for grain yield were not significant under favorable and heat stress treatments (Table 3 ). 
TABLE 2. Mean performance \pm standard error of $\mathrm{P}_{1}, \mathrm{P}_{2}, \mathrm{~F}_{1}, \mathrm{~F}_{2}, \mathrm{BC}_{1}$ and $\mathrm{BC}_{2}$ of three crosses combinations for various quantitative traits in bread wheat under favorable and heat stress conditions.

\begin{tabular}{|c|c|c|c|c|c|c|c|}
\hline \multirow{2}{*}{$\begin{array}{c}\text { Sowing } \\
\text { date }\end{array}$} & \multirow{2}{*}{ Crosses } & \multicolumn{6}{|c|}{ Generations } \\
\hline & & $\mathbf{P}_{1}$ & $\mathbf{P}_{2}$ & $\mathbf{F}_{1}$ & $\mathbf{F}_{2}$ & $\mathrm{BC}_{1}$ & $\mathrm{BC}_{2}$ \\
\hline \multicolumn{8}{|c|}{ Days to heading } \\
\hline Favorable & Cross 1 & $81.62 \pm 0.25$ & $79.30 \pm 0.19$ & $84.14 \pm 0.62$ & $80.64 \pm 0.32$ & $83.08 \pm 0.56$ & $74.86 \pm 0.47$ \\
\hline Heat stress & Cross 1 & $62.85 \pm 0.28$ & $63.44 \pm 0.21$ & $65.63 \pm 0.72$ & $59.67 \pm 0.38$ & $65.63 \pm 0.67$ & $60.64 \pm 0.54$ \\
\hline Favorable & Cross 2 & $98.33 \pm 0.15$ & $89.30 \pm 0.14$ & $95.84 \pm 0.36$ & $92.94 \pm 0.24$ & $91.86 \pm 0.32$ & $87.08 \pm 0.46$ \\
\hline Heat stress & Cross 2 & $80.63 \pm 0.17$ & $72.33 \pm 0.16$ & $78.59 \pm 0.41$ & $73.42 \pm 0.28$ & $76.24 \pm 0.36$ & $71.41 \pm 0.46$ \\
\hline Favorable & Cross 3 & $98.68 \pm 0.13$ & $91.68 \pm 0.14$ & $94.63 \pm 0.40$ & $91.68 \pm 0.45$ & $89.08 \pm 0.42$ & $86.86 \pm 0.35$ \\
\hline Heat stress & Cross 3 & $73.02 \pm 0.15$ & $68.76 \pm 0.16$ & $68.13 \pm 0.47$ & $64.18 \pm 0.54$ & $65.47 \pm 0.48$ & $63.84 \pm 0.41$ \\
\hline \multicolumn{8}{|c|}{ Spike length $(\mathrm{cm})$} \\
\hline Favorable & Cross 1 & $11.88 \pm 0.13$ & $10.00 \pm 0.15$ & $12.56 \pm 0.30$ & $11.11 \pm 0.22$ & $11.62 \pm 0.33$ & $10.38 \pm 0.26$ \\
\hline Heat stress & Cross 1 & $10.34 \pm 0.15$ & $8.40 \pm 0.17$ & $10.93 \pm 0.35$ & $9.11 \pm 0.25$ & $10.23 \pm 0.38$ & $8.93 \pm 0.30$ \\
\hline Favorable & Cross 2 & $10.0 \pm 0.14$ & $9.98 \pm 0.15$ & $11.56 \pm 0.46$ & $11.18 \pm 0.29$ & $12.42 \pm 0.47$ & $10.28 \pm 0.39$ \\
\hline Heat stress & Cross 2 & $8.98 \pm 0.16$ & $8.68 \pm 0.17$ & $9.94 \pm 0.52$ & $9.50 \pm 0.33$ & $10.81 \pm 0.53$ & $8.94 \pm 0.44$ \\
\hline Favorable & Cross 3 & $11.50 \pm 0.13$ & $9.40 \pm 0.19$ & $10.80 \pm 0.21$ & $10.60 \pm 0.14$ & $11.20 \pm 0.32$ & $9.40 \pm 0.23$ \\
\hline Heat stress & Cross 3 & $9.66 \pm 0.14$ & $7.99 \pm 0.22$ & $8.86 \pm 0.25$ & $8.27 \pm 0.17$ & $9.07 \pm 0.37$ & $7.71 \pm 0.27$ \\
\hline \multicolumn{8}{|c|}{ Number of spikes/plant } \\
\hline Favorable & Cross 1 & $10.80 \pm 0.09$ & $9.00 \pm 0.10$ & $12.60 \pm 0.32$ & $11.01 \pm 0.24$ & $10.24 \pm 0.26$ & $9.16 \pm 0.31$ \\
\hline Heat stress & Cross 1 & $7.78 \pm 0.12$ & $6.39 \pm 0.13$ & $9.20 \pm 0.40$ & $8.81 \pm 0.29$ & $7.48 \pm 0.32$ & $6.46 \pm 0.39$ \\
\hline Favorable & Cross 2 & $11.80 \pm 0.13$ & $7.54 \pm 0.13$ & $8.98 \pm 0.42$ & $8.44 \pm 0.37$ & $9.46 \pm 0.32$ & $8.32 \pm 0.42$ \\
\hline Heat stress & Cross 2 & $8.61 \pm 0.16$ & $5.43 \pm 0.16$ & $6.38 \pm 0.52$ & $6.37 \pm 0.25$ & $7.10 \pm 0.40$ & $5.74 \pm 0.52$ \\
\hline Favorable & Cross 3 & $15.64 \pm 0.14$ & $14.78 \pm 0.13$ & $16.46 \pm 0.33$ & $15.89 \pm 0.26$ & $17.12 \pm 0.32$ & $15.05 \pm 0.29$ \\
\hline Heat stress & Cross 3 & $11.89 \pm 0.16$ & $11.38 \pm 0.14$ & $12.35 \pm 0.37$ & $11.92 \pm 0.29$ & $13.18 \pm 0.36$ & $11.44 \pm 0.33$ \\
\hline \multicolumn{8}{|c|}{ Number of kernels/spike } \\
\hline Favorable & Cross 1 & $55.68 \pm 0.26$ & $44.00 \pm 0.27$ & $64.12 \pm 0.40$ & $58.66 \pm 0.31$ & $65.88 \pm 0.48$ & $63.66 \pm 0.48$ \\
\hline Heat stress & Cross 1 & $37.86 \pm 0.34$ & $29.48 \pm 0.34$ & $42.96 \pm 0.51$ & $36.37 \pm 0.40$ & $45.46 \pm 0.58$ & $43.29 \pm 0.60$ \\
\hline Favorable & Cross 2 & $53.57 \pm 0.26$ & $48.42 \pm 0.27$ & $58.24 \pm 0.73$ & $54.38 \pm 0.39$ & $57.77 \pm 0.66$ & $54.54 \pm 0.58$ \\
\hline Heat stress & Cross 2 & $36.96 \pm 0.34$ & $32.93 \pm 0.33$ & $39.02 \pm 0.91$ & $35.35 \pm 0.50$ & $39.28 \pm 0.82$ & $36.27 \pm 0.72$ \\
\hline Favorable & Cross 3 & $73.66 \pm 0.15$ & $64.88 \pm 0.12$ & $69.22 \pm 0.38$ & $67.46 \pm 0.22$ & $72.12 \pm 0.26$ & $67.89 \pm 0.34$ \\
\hline Heat stress & Cross 3 & $52.30 \pm 0.17$ & $46.71 \pm 0.15$ & $46.38 \pm 0.49$ & $42.50 \pm 0.29$ & $49.04 \pm 0.34$ & $45.49 \pm 0.44$ \\
\hline \multicolumn{8}{|c|}{1000 -Kernel weight $(\mathrm{g})$} \\
\hline Favorable & Cross 1 & $48.12 \pm 0.25$ & $40.00 \pm 0.23$ & $52.70 \pm 0.49$ & $49.22 \pm 0.32$ & $52.80 \pm 0.45$ & $50.44 \pm 0.39$ \\
\hline Heat stress & Cross 1 & $37.53 \pm 0.33$ & $30.80 \pm 0.31$ & $41.11 \pm 0.64$ & $37.41 \pm 0.43$ & $41.71 \pm 0.58$ & $39.34 \pm 0.50$ \\
\hline Favorable & Cross 2 & $49.00 \pm 0.25$ & $42.00 \pm 0.27$ & $56.00 \pm 0.79$ & $53.20 \pm 0.42$ & $56.0 \pm 0.65$ & $53.30 \pm 0.77$ \\
\hline Heat stress & Cross 2 & $39.20 \pm 0.32$ & $33.18 \pm 0.35$ & $43.68 \pm 1.03$ & $40.96 \pm 0.56$ & $45.36 \pm 0.83$ & $42.05 \pm 0.98$ \\
\hline Favorable & Cross 3 & $50.00 \pm 0.17$ & $47.80 \pm 0.19$ & $52.60 \pm 0.63$ & $48.80 \pm 0.26$ & $52.80 \pm 0.32$ & $49.80 \pm 0.52$ \\
\hline Heat stress & Cross 3 & $38.00 \pm 0.23$ & $35.85 \pm 0.25$ & $38.40 \pm 0.84$ & $34.65 \pm 0.36$ & $38.54 \pm 0.43$ & $36.35 \pm 0.70$ \\
\hline \multicolumn{8}{|c|}{ Grain yield/plant $(\mathrm{g})$} \\
\hline Favorable & Cross 1 & $30.78 \pm 0.24$ & $27.04 \pm 0.22$ & $34.24 \pm 0.63$ & $29.20 \pm 0.35$ & $33.98 \pm 0.38$ & $29.88 \pm 0.67$ \\
\hline Heat stress & Cross 1 & $19.39 \pm 0.30$ & $17.31 \pm 0.27$ & $20.89 \pm 0.78$ & $17.52 \pm 0.44$ & $21.07 \pm 0.46$ & $18.82 \pm 0.82$ \\
\hline Favorable & Cross 2 & $36.26 \pm 0.16$ & $34.56 \pm 0.19$ & $43.28 \pm 0.62$ & $39.36 \pm 0.33$ & $42.88 \pm 0.49$ & $40.24 \pm 0.62$ \\
\hline Heat stress & Cross 2 & $24.29 \pm 0.20$ & $22.81 \pm 0.23$ & $28.13 \pm 0.74$ & $24.80 \pm 0.41$ & $28.30 \pm 0.59$ & $26.16 \pm 0.75$ \\
\hline Favorable & Cross 3 & $37.78 \pm 0.25$ & $36.64 \pm 0.29$ & $40.87 \pm 0.74$ & $38.08 \pm 0.39$ & $40.24 \pm 0.42$ & $36.46 \pm 0.77$ \\
\hline Heat stress & Cross 3 & $23.42 \pm 0.31$ & $23.08 \pm 0.37$ & $24.52 \pm 0.94$ & $21.71 \pm 0.50$ & $25.35 \pm 0.53$ & $22.24 \pm 0.98$ \\
\hline
\end{tabular}

Cross $1=($ Giza $164 \times$ Qimma 4), Cross $2=($ Giza168 x Cham 6), Cross $3=($ Gemmeiza $9 \times$ Johara14 $)$

Egypt. J. Agron . 36, No.1 (2014) 
GENETIC ANALYSIS OF AGRONOMIC TRAITS...

TABLE 3. Scaling and joint scaling test of generation mean for various quantitative traits in the three crosses of bread wheat under favorable and heat stress conditions.

\begin{tabular}{|c|c|c|c|c|}
\hline \multirow{2}{*}{ Sowing date } & \multirow{2}{*}{ cross } & \multicolumn{3}{|c|}{ Scaling and joint scaling test } \\
\hline & & $\mathrm{A}$ & $\mathrm{B}$ & $\mathrm{C}$ \\
\hline \multicolumn{5}{|c|}{ Days to heading } \\
\hline Favorable & Cross 1 & 0.40 & $-13.72 * *$ & $-6.64 * *$ \\
\hline Heat stress & Cross 1 & 2.79 & $-7.80^{* *}$ & $-18.85^{* *}$ \\
\hline Favorable & Cross 2 & $-10.45 * *$ & $-10.98 * *$ & $-7.55 * *$ \\
\hline Heat stress & Cross 2 & $-6.73 * *$ & $-8.11 * *$ & $-16.45^{* *}$ \\
\hline Favorable & Cross 3 & $-15.15 * *$ & $-12.59 * *$ & $-12.90 * *$ \\
\hline Heat stress & Cross 3 & $-10.21 * *$ & $-9.21 * *$ & $-21.35^{* * *}$ \\
\hline \multicolumn{5}{|c|}{ Spike length } \\
\hline Favorable & Cross 1 & -1.20 & $-1.80 * *$ & $-2.56^{*}$ \\
\hline Heat stress & Cross 1 & -0.81 & $-1.47 *$ & $-4.15 * *$ \\
\hline Favorable & Cross 2 & $3.08 * *$ & -0.98 & 1.42 \\
\hline Heat stress & Cross 2 & $2.69^{*}$ & -0.74 & 0.47 \\
\hline Favorable & Cross 3 & 0.10 & $-1.40 *$ & -0.10 \\
\hline Heat stress & Cross 3 & -0.37 & $-1.43 *$ & $-2.29 * *$ \\
\hline \multicolumn{5}{|c|}{ Number of spikes/plant } \\
\hline Favorable & Cross 1 & $-2.92 * *$ & $-3.28 * *$ & -0.96 \\
\hline Heat stress & Cross 1 & $-2.02 * *$ & $-2.67 * *$ & 2.67 \\
\hline Favorable & Cross 2 & $-1.86^{*}$ & 0.12 & $-3.54 *$ \\
\hline Heat stress & Cross 2 & -0.80 & -0.32 & -1.31 \\
\hline Favorable & Cross 3 & $2.14 * *$ & -1.14 & 0.22 \\
\hline Heat stress & Cross 3 & $2.13 * *$ & -0.85 & -0.29 \\
\hline \multicolumn{5}{|c|}{ Number of kernels/spike } \\
\hline Favorable & Cross 1 & $11.96 * *$ & $19.20 * *$ & $6.72 * *$ \\
\hline Heat stress & Cross 1 & $10.09 * *$ & $14.14 * *$ & $-7.79 * *$ \\
\hline Favorable & Cross 2 & $3.73 *$ & 2.42 & -0.95 \\
\hline Heat stress & Cross 2 & 2.58 & 0.59 & $-6.54 *$ \\
\hline Favorable & Cross 3 & $1.36^{*}$ & $1.68 *$ & $-7.14 * *$ \\
\hline Heat stress & Cross 3 & -0.59 & $-2.12 *$ & $-21.77 * *$ \\
\hline \multicolumn{5}{|c|}{ 1000-grain weight } \\
\hline Favorable & Cross 1 & $4.78 * *$ & $8.18 * *$ & $3.36 * *$ \\
\hline Heat stress & Cross 1 & $4.78 * *$ & $6.78 * *$ & -0.92 \\
\hline Favorable & Cross 2 & $8.40 * *$ & $8.60 * *$ & $9.80 * *$ \\
\hline Heat stress & Cross 2 & $7.84 * *$ & $7.25 * *$ & 4.12 \\
\hline Favorable & Cross 3 & $3.00 * *$ & -0.80 & $-7.80 * *$ \\
\hline Heat stress & Cross 3 & 0.69 & -1.54 & $-12.05^{* *}$ \\
\hline \multicolumn{5}{|c|}{ Grain yield/plant } \\
\hline Favorable & Cross 1 & $2.94 * *$ & -1.52 & $-9.50 * *$ \\
\hline Heat stress & Cross 1 & 1.86 & -0.54 & $-8.39 * *$ \\
\hline Favorable & Cross 2 & $6.22 * *$ & 2.64 & 0.06 \\
\hline Heat stress & Cross 2 & $4.18 * *$ & 1.37 & -4.18 \\
\hline Favorable & Cross 3 & 1.83 & $-4.59 * *$ & -3.84 \\
\hline Heat stress & Cross 3 & 2.76 & -3.12 & $-8.73 * *$ \\
\hline
\end{tabular}

$* p<0.05, * * p<0.01$. 
While, the scaling test $\mathrm{B}$ in cross 2 for spike length, in crosses 2 and 3 for number of spikes/plant, in cross 2 for number of kernels/spike, in cross 3 for 1000-kernel weight and in crosses 1 and 2 for grain yield under favorable sown and heat stress treatments were found not significant. As well as, the scaling test $\mathrm{C}$ in cross 2 for spike length, in crosses 1 and 3 for number of spikes/plant and in cross 2 for grain yield under favorable sown and heat stress treatments showed not significant. These results, in general indicated that the presence of non-allelic interaction for all studied traits in all crosses under study except number of spikes/plant in cross 2 under heat stress. It was worthy to mention that if scaling test $\mathrm{A}, \mathrm{B}$ and $\mathrm{C}$ were significant this indicate to the inadequacy of the simple model in interpreting the differences between population means. Also, the scaling test estimates for the excepted traits indicated the absence of non-allelic interactions and additive-dominance mode was adequate. These results were in agreement with El-Aref et al. (2011) and Amin (2013).

\section{Gene action and epistasis}

The estimate of mean parameter $(\mathrm{m})$ for all studied traits which reflected the contribution due to the overall mean plus the locus effects and interactions of the fixed loci was found to be highly significant of the three crosses under favorable and heat stress treatments (Table 4). It was suggested that the additive (d) effect was significantly positive for all traits under favorable sown and heat stress. This clearly indicated the significant contribution of additive gene effects in the inheritance of these traits in respective crosses. Additive (d) gene effect was more important than dominance (h) in the genetic control of spike length, indicating that this character was relatively simply inherited (Sharma et al., 2003). Additive gene effect (a) was quiet small in magnitude relative to the dominance gene effects. Additive gene effect was found for number days to heading, spike length, number of spikes/ plant, number of kernels/ spike, 1000kernel weight and grain yield/ plant (Farag, 2009 and Hamam, 2013).

However, the dominance effects were reported for days to heading under heat stress (El-Sayed \& El-Shaarawy, 2006). The dominance effects (h) for number of kernels/spike, 1000-kernel weight and grain yield/plant in all crosses under favorable sown and heat stress was significant and positive. As well as for; days to heading and spike length in cross 1 were significant and positive under heat stress, indicating the importance of dominance gene effects in the inheritance of these traits; and their magnitude was also higher than that of additive effects, suggesting greater important of dominance effects in the expression of these traits. While days to heading in crosses 1 and 3 and number of spikes/plant in cross 1 were significant and negative under favorable sown indicate diminishing effect could occur in the expression of these traits. On the other hand, significant of (d) and (h) components indicated that both additive and dominance gene effects were important in the inheritance of these traits and selecting desirable traits would be effective in the late generations. The epistatic gene effects with higher estimate of $(\mathrm{h})$ effects could contribute a sizeable part of variation for these traits (Hendawy, 2003 and El-Aref et al., 2011).

Egypt. J. Agron . 36, No.1 (2014) 
TABLE 4. Estimates of gene effects and components of variance for quantitative traits in the three crosses of bread wheat under favorable and heat stress conditions.

\begin{tabular}{|c|c|c|c|c|c|c|c|c|}
\hline \multirow[b]{2}{*}{$\begin{array}{l}\text { Sowing } \\
\text { date }\end{array}$} & \multirow[b]{2}{*}{ cross } & \multicolumn{6}{|c|}{ Gene effects } & \multirow[b]{2}{*}{ Epistasis } \\
\hline & & Mean (m) & $\begin{array}{l}\text { Additive } \\
\text { (d) }\end{array}$ & $\begin{array}{c}\text { Dominance } \\
\text { (h) }\end{array}$ & $\begin{array}{l}\text { Additive } x \\
\text { Additive } \\
\text { (i) }\end{array}$ & $\begin{array}{c}\text { Additive } \mathbf{x} \\
\text { Dominance } \\
\text { (j) }\end{array}$ & $\begin{array}{c}\text { Diminance } x \\
\text { Dominance } \\
\text { (L) }\end{array}$ & \\
\hline \multicolumn{9}{|c|}{ Days to heading } \\
\hline Favorable & Cross 1 & $80.64 * *$ & $8.22 * *$ & -3.00 & $-6.68 * *$ & $7.06 * *$ & $20.00 * *$ & $\mathrm{D}$ \\
\hline Heat stress & Cross 1 & $59.67 * *$ & $5.00 * *$ & $16.33^{* *}$ & $13.85^{* *}$ & $5.29 * *$ & $-8.84 *$ & $\mathrm{D}$ \\
\hline Favorable & Cross 2 & $92.94 * *$ & $4.78 * *$ & $-11.86^{* *}$ & $-13.88^{* *}$ & 0.27 & 35.31 ** & $\mathrm{D}$ \\
\hline Heat stress & Cross 2 & $73.42 * *$ & $4.84 * *$ & $3.72 *$ & 1.61 & 0.69 & 13.23 ** & $\mathrm{C}$ \\
\hline Favorable & Cross 3 & $91.68 * *$ & $2.22 * *$ & $-15.39 * *$ & $-14.84^{* *}$ & $-1.28 *$ & $42.58 * *$ & $\mathrm{D}$ \\
\hline Heat stress & Cross 3 & $64.18^{* *}$ & $1.63 * *$ & -0.83 & 1.93 & -0.50 & 17.49 ** & $\mathrm{D}$ \\
\hline \multicolumn{9}{|c|}{ Spike length } \\
\hline Favorable & Cross 1 & 11.11 ** & $1.24 * *$ & 1.18 & -0.44 & 0.30 & 3.44 & $\mathrm{C}$ \\
\hline Heat stress & Cross 1 & $9.11 * *$ & $1.30 * *$ & $3.42 *$ & 1.86 & 0.33 & 0.42 & $\mathrm{C}$ \\
\hline Favorable & Cross 2 & $11.18^{* *}$ & $2.14 * *$ & 2.15 & 0.68 & $2.03 * *$ & -2.78 & $\mathrm{D}$ \\
\hline Heat stress & Cross 2 & $9.50 * *$ & $1.86 * *$ & 2.60 & 1.49 & $1.72 * *$ & -3.44 & $\mathrm{D}$ \\
\hline Favorable & Cross 3 & $10.60 * *$ & $1.80 * *$ & -0.85 & -1.20 & 0.75 & 2.50 & $\mathrm{D}$ \\
\hline Heat stress & Cross 3 & $8.27 * *$ & $1.36 * *$ & 0.52 & 0.49 & 0.53 & 1.31 & $\mathrm{C}$ \\
\hline \multicolumn{9}{|c|}{ Number of spikes/plant } \\
\hline Favorable & Cross 1 & $11.01 * *$ & $1.08 * *$ & $-2.54 *$ & $-5.24 * *$ & 0.18 & $11.44 * *$ & $\mathrm{D}$ \\
\hline Heat stress & Cross 1 & $8.81 * *$ & $1.02 *$ & $-5.25 * *$ & $-7.37 * *$ & 0.32 & $12.06^{* * *}$ & $\mathrm{D}$ \\
\hline Favorable & Cross 2 & $8.44 * *$ & $1.14 *$ & 1.11 & 1.80 & -0.99 & -0.06 & $\mathrm{D}$ \\
\hline Heat stress & Cross 2 & $6.37 * *$ & $1.35^{*}$ & -0.46 & 0.18 & -0.24 & 0.94 & $\mathrm{D}$ \\
\hline Favorable & Cross 3 & $15.89 * *$ & $2.07 * *$ & 2.03 & 0.78 & $1.64 * *$ & -1.78 & $\mathrm{D}$ \\
\hline Heat stress & Cross 3 & $11.92 * *$ & $1.74 * *$ & 2.28 & 1.57 & $1.49 * *$ & -2.85 & $\mathrm{D}$ \\
\hline \multicolumn{9}{|c|}{ Number of kernels/spike } \\
\hline Favorable & Cross 1 & $58.66^{* * *}$ & $2.22 * *$ & $38.72 * *$ & $24.44 * *$ & $-3.62 * *$ & $-55.60 * *$ & $\mathrm{D}$ \\
\hline Heat stress & Cross 1 & $36.37 * *$ & $0.87 * *$ & $41.26 * *$ & $31.97 * *$ & $-3.32 *$ & $-56.16^{* *}$ & $\mathrm{D}$ \\
\hline Favorable & Cross 2 & $54.38^{* * *}$ & $3.23 * *$ & $14.35^{* *}$ & $7.10 * *$ & 0.66 & $-13.25 * *$ & $\mathrm{D}$ \\
\hline Heat stress & Cross 2 & $35.35^{* *}$ & $3.01 * *$ & $13.79 * *$ & $9.72 * *$ & 1.00 & $-12.89 * *$ & $\mathrm{D}$ \\
\hline Favorable & Cross $\mathbf{3}$ & $67.46^{* * *}$ & $4.23 * *$ & $10.13^{* *}$ & $10.18^{* *}$ & -0.16 & $-13.22 * *$ & $\mathrm{D}$ \\
\hline Heat stress & Cross 3 & $42.50 * *$ & $3.56 * *$ & $15.93 * *$ & $19.06^{* *}$ & 0.76 & $-16.35 * *$ & $\mathrm{D}$ \\
\hline \multicolumn{9}{|c|}{ 1000-Kernel/spike } \\
\hline Favorable & Cross 1 & $49.22 * *$ & $2.36 * *$ & $18.24 * *$ & $9.60 * *$ & $-1.70 * *$ & $-22.56^{* *}$ & $\mathrm{D}$ \\
\hline Heat stress & Cross 1 & $37.41 * *$ & $2.37 * *$ & $19.42 * *$ & $12.48 * *$ & -1.00 & $-24.05 * *$ & $\mathrm{D}$ \\
\hline Favorable & Cross 2 & $53.20^{* * *}$ & $3.40 * *$ & $17.70 * *$ & $7.20 * *$ & -0.10 & $-24.20 * *$ & $\mathrm{D}$ \\
\hline Heat stress & Cross 2 & $40.96 * *$ & $3.31 * *$ & $18.46^{* *}$ & $10.97 * *$ & 0.30 & $-26.06^{* *}$ & $\mathrm{D}$ \\
\hline Favorable & $\begin{array}{ll}\text { Cross } 3 \\
\end{array}$ & $48.80^{* *}$ & $3.00 * *$ & $13.70 * *$ & $10.00 * *$ & $1.90 * *$ & $-12.20^{* *}$ & $\mathrm{D}$ \\
\hline Heat stress & Cross 3 & $34.65^{* *}$ & $2.19 * *$ & $12.68 * *$ & $11.20 * *$ & 1.11 & $-10.35^{* *}$ & $\mathrm{D}$ \\
\hline \multicolumn{9}{|c|}{ Grain yield/plant } \\
\hline Favorable & Cross 1 & $29.20 * *$ & $4.10 * *$ & $16.25^{* *}$ & $10.92 * *$ & $2.23 * *$ & $-12.34 * *$ & $\mathrm{D}$ \\
\hline Heat stress & Cross 1 & $17.52 * *$ & $2.24 *$ & $12.24 * *$ & $9.70 * *$ & 1.20 & $-11.02 *$ & $\mathrm{D}$ \\
\hline Favorable & $\begin{array}{l}\text { Cross } 2 \\
\end{array}$ & $39.36^{* *}$ & $2.64 * *$ & $16.67 * *$ & $8.80 * *$ & $1.79 *$ & $-17.66^{* *}$ & $\mathrm{D}$ \\
\hline Heat stress & Cross 2 & $24.80^{* * *}$ & $2.14 *$ & $14.31 * *$ & $9.73 * *$ & 1.40 & $-15.27 * *$ & $\mathrm{D}$ \\
\hline Favorable & $\begin{array}{l}\text { Cross } 3 \\
\end{array}$ & $38.08 * *$ & $3.78 * *$ & $4.74 *$ & 1.08 & $3.21 * *$ & 1.68 & $\mathrm{C}$ \\
\hline Heat stress & Cross 3 & $21.71^{* *}$ & $3.11 * *$ & $9.63 * *$ & $8.36 * *$ & $2.94 * *$ & -7.99 & $\mathrm{D}$ \\
\hline
\end{tabular}


Considering the contribution of epistatic gene effects, additive $\mathrm{x}$ additive (i) interaction had enhancing effect in the expression for; number of kernels/spike, 1000-kernel weight and grain yield/plant in all crosses under favorable sown and heat stress treatments except grain yield/plant in cross 3 under favorable sown treatment were highly significant and positive. As well as for; days to heading in cross 1 was positive and significant under heat stress. While days to heading in all crosses and number of spikes/plant in cross 1 were negative and significant under favorable sown treatment (Table 4).

On the other hand, highly positive and significant additive $\times$ dominance $(\mathrm{j})$ types of epistasis was found for; days to heading in cross 1; spike length in the cross 2; number of spikes/plant in the cross 3 and grain yield/plant in the cross 3 under favorable sown and heat stress treatments. As well as, 1000-kernel weight in cross 3 and grain yield/plant in the crosses 1 and 2 under favorable sown treatment were positive and significant. However, highly negative and significant were found for number of kernels/spike under favorable sown and heat stress treatments, days to heading in cross 3 and 1000-kernel weight in the cross 1 under favorable sown treatment.

The dominance $\times$ dominance $(\mathrm{L})$ interactions with higher magnitude were significant or highly significant positive for; days to heading in the two crosses 2 and 3 and number of spikes/plant in the cross 1 under favorable sown and heat stress treatments, days to heading in cross 1 only under favorable sown date. On the other hand, number of kernels/spike in all crosses; 1000-kernel weight in all crosses and grain yield/plant in the two crosses 1 and 2 under favorable sown and heat stress treatments were highly negative and significant. The negative (L) interactions indicating their reducing effect in the expression of some of the traits in the present study. These results confirm the importance role of dominance $\mathrm{x}$ dominance gene action in the genetic system. The same results were reported by El-Sayed \& El-Shaarawy (2006) and Hamam (2013).

All the three types of epistatic gene interactions ( $i, j$ and $L$ ) were significant and were associated significant and negative dominance effect for days to heading; with significant and positive dominance effect for number of kernels/spike all crosses, suggesting that materials could be selected for earliness with high grains intensity in wheat.

Complementary epistasis was revealed by similar signs of (h) and (L), while differences, in signs of (h) and (L) indicate duplicate epistasis. The contribution of the traits was not unidirectional and in some cases, it had reducing (-) effects, whereas, in other increasing (+) effects. The results in Table 4 showed that duplicate epistasis was prevailing for all traits studied except; days to heading in cross 2 and spike length in crosses 1 and 3 under heat stress and spike length in cross 1 and grain yield/plant in cross 3 only under favorable sown showed complementary epistasis effects. This indicated that duplicate epitasis was of greater importance than complementary epitasis for most studied traits. These

Egypt. J. Agron . 36, No.1 (2014) 
results were in agreement with those of Sharma et al. (2003), Abd-El-Aty \& Katta (2007), Saint Pierre et al. (2010) and Yadav \& Singh (2011).

The three parameter models was applied for number of spikes/plant in cross 2 under heat stress as the scaling test indicated absence of non-allelic interaction (Table 5). The mean effect [m] was highly significant; the additive gene effect [d] was highly significant positive while the dominance [h] gene effect was negative and not significant for number of spikes/plant in cross 2 under heat stress. This would indicate the additive gene effect play the major role in controlling the genetic system of the number of spikes/plant in cross 2 under heat stress. The character was governed by additive gene effects, although the effect of contributions was reducing. Similar results were obtained by Rahman \& Saad (2000).

TABLE 5. Estimates of $m$, $d$ and $h$ for number of spikes/plant for the noninteracting cross 2 , Giza168 $x$ Cham 6 of bread wheat using three parameter models of Jinks and Jones under heat stress.

\begin{tabular}{|c|c|c|c|}
\hline Character & \multicolumn{3}{|c|}{ Gene effects } \\
\hline & {$[\mathbf{m}]$} & {$[\mathbf{h}]$} \\
\hline \multirow{2}{*}{ Number of spikes/plant } & \multicolumn{3}{|c|}{ Cross $2=($ Giza168 $\times$ Cham 6) } \\
\cline { 2 - 4 } & $6.8 * * \pm 1.65$ & $1.59 * * \pm 0.11$ & $-1.40 \pm 4.4$ \\
\hline
\end{tabular}

$\mathrm{m}=$ mean, $\mathrm{d}=$ additive effect, $\mathrm{h}=$ dominance effect .

$* p<0.05, * * p<0.01$.

The relative magnitude of additive and dominance effects for the traits in each cross varied, leading to the variation in the inheritance. Those traits were controlled by additive (d) and additive $\mathrm{x}$ additive (i) gene effects, can be improved by pedigree selection whereas those were under the control of dominance (h) and dominance $\mathrm{x}$ dominance $(\mathrm{L})$, heterosis breeding might be effective for the development of superior populations (Rahman \& Saad, 2000).

Heterosis, inbreeding depression, heritability and genetic advance

Heterosis and inbreeding effect (\%)

Heterosis was expressed as the percentage deviation of $F_{1}$ mean performance from the better or mid parent of different traits. In this concern, percentages of heterosis over better and mid-parent values under favorable sown and heat stress treatments were presented in Table 6. Positive highly significant heterosis over mid and better parent values were obtained for; days to heading in two crosses 1 and 2, spike length in two crosses 1 and 2, number of spikes/plant in two crosses 1 and 3, number of kernels/spike in two crosses 1 and 2, 1000-kernel weight in two crosses 1 and 2 and grain yield/plant in all crosses under favorable sown and heat stress treatments. As well as for; spike length, number of spikes/plant, number of kernels/spike and 1000-kernel weight in cross 3 were found positive highly significant heterosis over mid and better parents values only under favorable sown. Moreover, spike length and number of spikes/plant in cross 3 were found positive highly significant 
heterosis over better parent values only under heat stress. While negative highly significant heterosis for mid-parent were obtained for, days to heading in cross 3; number of spikes/plant in cross 2 and number of kernels/spike in cross 3 under heat stress treatment. As well as, days to heading in cross 3 and number of kernels/spike in cross 3 were found negative insignificant heterosis over better parent values only under heat stress. A significant and negative heterotic effect for earliness in some crosses was previously detected by Abd El-Aty \& Katta (2007) and Yadav \& Singh (2011). On the other hand, significant positive heterotic effects relative to the higher parents were found for spike length by Sharma et al. (2003) and for 1000-kernel/weight and grain yield/plant by Farag (2009) and Hamam (2013).

\section{Inbreeding depression}

Measured as reduction in performance of $F_{2}$ generation due to inbreeding presented in Table 6. Results showed that significant positive values for all traits studied under favorable sown and heat stress treatments except; spike length in cross 2 and number of spikes/plant in two crosses 2 and 3 under favorable sown and heat stress treatments were not significant positive values. As well as, Inbreeding depression recorded not significant positive values for spike length in cross 3 only under favorable sown and number of spikes/plant in crosses 1 under heat stress. While number of spikes/plant in cross 1 under heat stress treatment was not significant positive value. These results were in close agreements with those of Abd El-Aty \& Katta (2007), Yadav \& Singh (2011) and Hamam (2013).

\section{Potence ratio}

The level of degree of dominance of six various traits computed using generation means and presented as potence ratio in Table 6. It could be summarized that, concerning days to heading, spike length, number of spikes/plant, number of kernels/spike, 1000-kernel weight and grain yield/plant results of potence ratio for most cases in $F_{1}$ and $F_{2}$ exceeded unity, either with positive or negative sign indicating that the over dominance existed in the heredity found for all the traits studied with some exceptions. The results showed partial dominance were found for days to heading in cross 2 in $F_{1}$ under favorable sown and heat and for $F_{1}$ only in the cross 3 under favorable sown and for $F_{2}$ in crosses 1 and 2 only under favorable sown. Spike length in cross 3 in $F_{1}$ under favorable sown and heat stress treatments, for $F_{2}$ in crosses 1 and 3 under favorable sown and in cross 1 also under heat stress were found partial dominance. Number of spikes/plant in cross 2 in $F_{1}$, for number of kernels/spike in cross 3 (for $\mathrm{F}_{1}$ and $\mathrm{F}_{2}$ ) only under favorable sown and in cross 2 for $F_{2}$ under heat stress revealed partial dominance. As well as partial dominance was indicated for 1000-kernel weight for $F_{2}$ only in cross 3 under favorable sown and for grain yield/plant in cross 1 in $\mathrm{F}_{2}$ under favorable sown. These results were harmony with those obtained by Darwish \& Ashoush (2003), Abd El-Aty \& Katta (2007) and Yadav \& Singh (2011).

Egypt. J. Agron . 36, No.1 (2014) 
TABLE 6. Genetic advance, heterosis relative to mid-parent (M.P) and better parent (B.P), inbreeding depression in $F_{2}$, potence ratio in $F_{1}$ and $F_{2}$ and heritability in $\mathbf{F}_{2}$ for studied characters in bread wheat under favorable and heat stress conditions.

\begin{tabular}{|c|c|c|c|c|c|c|c|c|c|}
\hline \multirow[b]{2}{*}{$\begin{array}{l}\text { Sowing } \\
\text { date }\end{array}$} & \multirow[b]{2}{*}{ Cross } & \multirow{2}{*}{$\begin{array}{c}\text { Genetic } \\
\text { advance } \\
\%\end{array}$} & \multicolumn{2}{|c|}{ Heterosis (\%) } & \multirow{2}{*}{$\begin{array}{c}\text { Inbreeding } \\
\text { depression } \\
(\%) F_{2}\end{array}$} & \multicolumn{2}{|c|}{ Potence ratio } & \multicolumn{2}{|c|}{$\begin{array}{c}\text { Heritability } \\
(\%) \mathbf{F}_{2}\end{array}$} \\
\hline & & & M.P & B.P & & $\mathbf{F}_{1}$ & $\mathbf{F}_{2}$ & $\begin{array}{l}\text { Broad } \\
\text { sense }\end{array}$ & $\begin{array}{l}\text { Narrow } \\
\text { sense }\end{array}$ \\
\hline \multicolumn{10}{|c|}{ Days to heading } \\
\hline Favorable & \begin{tabular}{|l|} 
Cross 1 \\
\end{tabular} & 10.50 & $4.57 * *$ & $6.10^{* *}$ & $4.16 * *$ & 3.17 & 0.31 & 90.81 & 68.05 \\
\hline Heat stress & \begin{tabular}{|l|} 
Cross 1 \\
\end{tabular} & 17.02 & $3.94 * *$ & $3.45 * *$ & $9.07 * *$ & \begin{tabular}{|l|}
-8.39 \\
\end{tabular} & 23.42 & 91.57 & 70.68 \\
\hline Favorable & \begin{tabular}{|c|} 
Cross 2 \\
\end{tabular} & 7.02 & $2.16^{* * *}$ & $7.32^{* *}$ & $3.03 * *$ & 0.45 & -0.39 & 93.25 & 63.33 \\
\hline Heat stress & Cross 2 & 10.25 & $2.75^{* *}$ & $8.65^{* *}$ & $6.57 * *$ & 0.51 & -1.47 & \begin{tabular}{|l|}
93.60 \\
\end{tabular} & 64.82 \\
\hline Favorable & \begin{tabular}{|l|} 
Cross $\mathbf{3}$ \\
\end{tabular} & 14.03 & -0.58 & $3.22 * *$ & $3.12 * *$ & -0.16 & -2.00 & \begin{tabular}{|l|}
98.14 \\
\end{tabular} & 92.69 \\
\hline Heat stress & \begin{tabular}{|l|} 
Cross 3 \\
\end{tabular} & 24.29 & $-3.89 * *$ & -0.91 & $5.81 * *$ & -1.29 & -6.30 & 98.28 & 93.45 \\
\hline \multicolumn{10}{|c|}{ Spike length } \\
\hline Favorable & \begin{tabular}{|l|} 
Cross 1 \\
\end{tabular} & 53.66 & $14.81 * *$ & $25.60 * *$ & $11.54 * *$ & 1.72 & 0.36 & 93.01 & 78.41 \\
\hline Heat stress & \begin{tabular}{|l|} 
Cross 1 \\
\end{tabular} & 75.45 & $16.65 * *$ & $30.09 * *$ & $16.63^{* * *}$ & 1.61 & -0.53 & 93.26 & 79.00 \\
\hline Favorable & \begin{tabular}{|l|} 
Cross 2 \\
\end{tabular} & 71.42 & $14.57 * *$ & $15.83 * *$ & & 13.36 & 19.82 & \begin{tabular}{|l|}
94.51 \\
\end{tabular} & 73.76 \\
\hline Heat stress & \begin{tabular}{|l|} 
Cross 2 \\
\end{tabular} & 96.07 & $12.60 * *$ & $14.50 * *$ & 4.41 & 7.58 & 9.18 & \begin{tabular}{|l|}
94.79 \\
\end{tabular} & 74.61 \\
\hline Favorable & \begin{tabular}{|l|} 
Cross $\mathbf{3}$ \\
\end{tabular} & 32.76 & $3.35 * *$ & $14.89^{* * *}$ & 1.85 & 0.33 & 0.29 & \begin{tabular}{|l|}
85.15 \\
\end{tabular} & 34.26 \\
\hline Heat stress & Cross 3 & 51.50 & 0.35 & $10.84 * *$ & $6.64 *$ & 0.04 & -1.33 & 86.28 & 42.22 \\
\hline \multicolumn{10}{|c|}{ Number of spikes/plant } \\
\hline Favorable & \begin{tabular}{|l|} 
Cross 1 \\
\end{tabular} & 61.16 & $27.27 * *$ & $40.00^{* *}$ & $12.62^{* *}$ & 3.00 & 2.47 & 96.31 & 84.90 \\
\hline Heat & \begin{tabular}{|l|} 
Cross 1 \\
\end{tabular} & 88.91 & 29.8 & $43.94 * *$ & & & 4.89 & \begin{tabular}{|l|}
92.57 \\
\end{tabular} & 84.04 \\
\hline Favorable & \begin{tabular}{|l|} 
Cross $\mathbf{2}$ \\
\end{tabular} & 88.52 & $-7.14 * *$ & $19.10^{* *}$ & 6 & -0.32 & -1.15 & 94.98 & 78.34 \\
\hline Heat stress & \begin{tabular}{|l|} 
Cross 2 \\
\end{tabular} & 94.15 & $-9.19 * *$ & $17.44 * *$ & 0.06 & -0.41 & -0.82 & 82.90 & 50.10 \\
\hline Favorable & Cross 3 & 45.36 & $8.22 * *$ & $5.24 * *$ & 3.4 & 2.91 & 3.16 & 95.17 & 85.16 \\
\hline Heat stress & \begin{tabular}{|l|} 
Cross 3 \\
\end{tabular} & 68.37 & $6.12^{* *}$ & $3.86^{* *}$ & 3.46 & 2.81 & 2.25 & \begin{tabular}{|l|}
95.19 \\
\end{tabular} & 85.13 \\
\hline \multicolumn{10}{|c|}{ Number of kernels/spike } \\
\hline Favorable & \begin{tabular}{|l|} 
Cross 1 \\
\end{tabular} & 13.87 & $28.65 * *$ & $15.16^{* * *}$ & $8.52 * *$ & 2.45 & 3.02 & \begin{tabular}{|c|}
90.11 \\
\end{tabular} & 68.80 \\
\hline Heat stress & \begin{tabular}{|l|} 
Cross 1 \\
\end{tabular} & 28.98 & $27.59 * *$ & $13.46^{* * *}$ & $15.34 * *$ & 2.22 & 1.29 & \begin{tabular}{|l|}
90.47 \\
\end{tabular} & 72.45 \\
\hline Favorable & \begin{tabular}{|l|} 
Cross 2 \\
\end{tabular} & 18.96 & $14.21 * *$ & $20.28^{* *}$ & $6.63 * *$ & 2.81 & 2.63 & \begin{tabular}{|l|}
90.74 \\
\end{tabular} & 68.46 \\
\hline Heat stress & \begin{tabular}{|l|} 
Cross 2 \\
\end{tabular} & 37.16 & $11.67 * *$ & $18.51^{* * *}$ & $9.41 * *$ & 2.02 & 0.40 & \begin{tabular}{|l|}
91.03 \\
\end{tabular} & 70.22 \\
\hline Favorable & \begin{tabular}{|l|} 
Cross $\mathbf{3}$ \\
\end{tabular} & 8.78 & -0.07 & $6.69 * *$ & $2.54 * *$ & -0.01 & -0.82 & \begin{tabular}{|l|}
92.43 \\
\end{tabular} & 78.91 \\
\hline Heat stress & \begin{tabular}{|l|} 
Cross $\mathbf{3}$ \\
\end{tabular} & 18.53 & $-6.32 * *$ & -0.72 & $8.36 * *$ & -1.12 & -5.02 & 93.07 & 79.95 \\
\hline \multicolumn{10}{|c|}{ 1000-Kernel/spike } \\
\hline Favorable & \begin{tabular}{|l|} 
Cross 1 \\
\end{tabular} & 17.23 & 19.61** & $31.75^{* *}$ & $6.60 * *$ & 2.13 & 2.54 & \begin{tabular}{|l|}
90.96 \\
\end{tabular} & 80.39 \\
\hline Heat stress & Cross 1 & 30.44 & $20.31 * *$ & 33.46 ** & $9.00 * *$ & 2.06 & 1.92 & 91.14 & 81.96 \\
\hline Favorable & \begin{tabular}{|l|} 
Cross 2 \\
\end{tabular} & 21.15 & $23.08 * *$ & 33.3 & $5.00 * *$ & 3.00 & 4.40 & 91.96 & 62.52 \\
\hline Heat stress & \begin{tabular}{|l|} 
Cross 2 \\
\end{tabular} & 36.74 & $20.70 * *$ & $31.65^{* *}$ & $6.22 *$ & 2.49 & 3.17 & \begin{tabular}{|l|}
92.48 \\
\end{tabular} & 66.97 \\
\hline Favorable & \begin{tabular}{|l|} 
Cross $\mathbf{3}$ \\
\end{tabular} & 13.82 & $7.57 * *$ & $5.20 * *$ & $7.22 * *$ & 3.36 & \begin{tabular}{|c|}
-0.18 \\
\end{tabular} & \begin{tabular}{|l|}
89.03 \\
\end{tabular} & 67.72 \\
\hline Heat stress & \begin{tabular}{|l|} 
Cross $\mathbf{3}$ \\
\end{tabular} & 27.05 & $3.99 * *$ & 1.05 & $9.77 * *$ & 1.37 & -4.24 & 89.66 & 69.60 \\
\hline \multicolumn{10}{|c|}{ Grain yield/plant } \\
\hline Favorable & \begin{tabular}{|l|} 
Cross 1 \\
\end{tabular} & 31.91 & $18.44 * *$ & $26.63 * *$ & $14.72 * *$ & 2.85 & 0.31 & \begin{tabular}{|l|}
91.39 \\
\end{tabular} & 70.22 \\
\hline Heat stress & \begin{tabular}{|l|} 
Cross 1 \\
\end{tabular} & 66.68 & $13.83 * *$ & 20.69 ** & $16.12^{* * *}$ & 2.43 & -1.59 & \begin{tabular}{|l|}
91.66 \\
\end{tabular} & 72.39 \\
\hline Favorable & \begin{tabular}{|l|} 
Cross 2 \\
\end{tabular} & 22.80 & $22.23 * *$ & $25.23^{* *}$ & $9.06 * *$ & 9.26 & 9.29 & \begin{tabular}{|c|}
93.34 \\
\end{tabular} & 63.26 \\
\hline Heat stress & \begin{tabular}{|l|} 
Cross 2 \\
\end{tabular} & 45.49 & $19.45^{* *}$ & $23.33 * *$ & $11.86^{* * *}$ & 6.17 & 3.35 & \begin{tabular}{|l|}
93.86 \\
\end{tabular} & 66.07 \\
\hline Favorable & Cross $\mathbf{3}$ & 27.05 & $9.84 * *$ & $11.54 * *$ & $6.83 * *$ & 6.42 & 3.05 & 90.65 & 68.85 \\
\hline Heat stress & \begin{tabular}{|l|} 
Cross $\mathbf{3}$ \\
\end{tabular} & 61.50 & $5.46^{* * *}$ & $6.23 * *$ & 11.49 ** & 7.45 & -18.19 & 91.08 & 70.36 \\
\hline
\end{tabular}


The broad and narrow sense heritability

Heritability estimates in broad sense were relatively high for all studied traits in all crosses, ranged from $85.15 \%$ and $86.28 \%$ for spike length in cross 3 to $98.14 \%$ and $98.28 \%$ for days to heading in cross 3 under favorable sown and heat stress treatments, respectively (Table 6). While, heritability estimates in narrow sense were moderate to low for all studied traits in all crosses, ranged from $34.26 \%$ and $42.22 \%$ for spike length in cross 3 to $92.69 \%$ and $93.45 \%$ for days to heading in cross 3 under favorable sown and heat stress treatments respectively, indicating that these traits greatly affected by non-additive and environmental effects. These results were coincident with those reported by El-Sayed \& El-Shaarawy (2006) and Khaled (2007). Talebi \& Fayyaz (2012) reported that broad sense heritability estimates was very high under both control and stress conditions, for number of kernels/spike, while broad sense heritability significantly decreased under stress conditions for 1000-grain weight. The degree of improving studied traits were based on the high heritability and genetic advance shown by the different characters, especially; spike length, number of spikes/plant, number of kernels/spike, 1000-kernel weight and grain yield/plant. Determinant genetic effects of the phenotypic expression of these characters were fundamentally of the additive type. For this reason, a high response should be achievable after several selection cycles. The development of crosses adapted to the heat stress conditions depends on improvement of potential yield and yield evaluation under high temperature. Breeding strategies like diallel selective mating in early segregating generation followed by recurrent selection might be appropriate approach toward genetic improvement of bread wheat.

\section{The expected genetic advance}

The gain from selection as $\%$ of $F_{2}$ means (Table 6) was highest for all crosses for number of spikes/plant followed by spike length, number of kernels/spike, 1000-kernel weight and grain yield/plant and lower for days to heading. The expected genetic advance as percent of $\mathrm{F}_{2}$ ranged from $(7.02 \%)$ for days to heading in cross 2 to $(10.25 \%)$ for days to heading in cross 2 under favorable sown and heat stress treatments, respectively and ranged from $(88.52 \%)$ for number of spikes/plant in cross 2 to $(96.07 \%)$ for spike length in cross 2 under favorable sown and heat stress treatments, respectively (Table 6). These results indicated the possibility of practicing selection in early generations and obtain high yielding genotypes. Therefore, selection in those particular populations should be effective and satisfactory for successful breeding purposes. Substantial progress to obtain desirable segregants for yield and its components in the F3 generation could be achieved by selection of the most desirable $10 \%$ plants in the $\mathrm{F}_{2}$ generation. El-Sherbeny et al. (2000) reported that gain for selection was high for 100 kernel weight followed by number of spikes/pant and grain yield/plant.

Egypt. J. Agron . 36, No.1 (2014) 


\section{Conclusion}

These results suggested that selection in $\mathrm{F}_{2}$ population would be effective to improve these characters in early generations of wheat breeding under favorable and heat stress condition. It can be concluded that the degree of improving studied traits based on the high heritability and positive additive genetic advance shown by the different traits, especially; number of spikes/plant, number of kernels/spike, 1000-kernel weight and grain yield/plant. Determinant genetic effects of the phenotypic expression of these traits were fundamentally of the additive type. For this reason, a high response should be achievable after several selection cycles. The development of varieties adapted to the heat conditions depends on improvement of potential yield and yield evaluation in different environments. Generally, the most promising crosses were the cross 1 (Giza164 $\mathrm{x}$ Qimma 4) and cross 3 (Gemmeiza 9 x Johara14) were found to higher in magnitude which had high genetic advance associated with high heritability and would be interest in breeding programs for evolving better wheat yield and yield component traits in bread wheat under normal and heat stress.

\section{References}

Abd El-Aty, M.S. and Katta, Y.S. (2007) Estimation of Genetic parameters using five populations in three bread wheat crosses. Egypt J. Plant Breed, 11(2), 627 -639.

Allard, R.W. (1960) "Principles of Plant Breeding”. John Wiley and Sons, Inc. New York, NY.

Amin, I.A. (2013) Genetic behaviour of some agronomic traits in two durum wheat crosses under heat stress. Alex. J. Agric. Res. 58 (1), 53-66.

Araus, J.L., Villegas, D., Aparicio, N., del Moral L.F.G., El Hani, S., Rharrabti, Y., Ferrio, J.P. and Royo, C. (2003) Environmental factors determining carbon isotope discrimination and yield in durum wheat under Mediterranean conditions. Crop Sci. 43,170-180.

Bayoumi, T.Y., Eid, Manal H. and Metwali, E.M. (2008) Application of physiological and biochemical indices as a screening technique for drought tolerance in wheat genotypes. African J. of Biotechnology, 7 (14), 2341-2352.

Cargnin, A., Souza, M.A., Carneiro, P.C.S. and Sofiatti,V. (2006) Interação entre genótipos e ambientes e implicações em gan- hos com seleção em trigo. Pesquisa Agr opecuária Brasi- leira. 41, 987.

Darwish, I.H. and Ashoush, H.A. (2003) Heterosis, gene effects, heritability and genetic advance in bread wheat. Minufyia J. Agric. Res. 28, 433. 
El-Aref, Kh.A.O., Tammam, A.M., Ibrahim, M.M. and Koubisy, Y.S. (2011) Generation mean analysis in bread wheat under drought conditions. Egypt. J. Appl. Sci. 26(2), 187-208.

El-Marakby, A. M., Mohamed, A. A., Tolba, A. M. and Saleh, S. H. (2007) Nature of gene action in the inheritance of earliness grain yield and quality traits in diallel crosses of bread wheat under different environments. Egyptian Journal of Plant Breeding, 11, 75 .

El-Sayed, E.A.M. and El-Shaarawy, G.A. (2006) Genetical studies on yield and some agronomic characters in some bread wheat (Triticum aestivum L.) crosses. J. Agric. Sci. Mansoura Univ. 31, 4901.

El-Sherbeny, G.A.R, Motawea, M.H., Hamada, M. S. and Baenziger, P.S. (2000) Nature of gene action controlling yield and its components in three crosses involving Egyptian and exotic bread wheat germplasm. Assiut. J. Agric Sci. 31, 203.

F.A.O (2012) (http://faostat.fao.org/site/339/default.aspx) F.A.O Statistic Production Year Book.

Farag, H.I.A. (2009) Inheritance of yield and its components in bread wheat (Triticum aestivum L.) using six parameter model under Ras Sudr Conditions. $6^{\text {th }}$ International Plant Breeding Conference, Ismailia, Egypt, May, 3-5, pp.90-112.

Gamble, E.E. (1962) Gene effects in corn (Zea mays L) I. Separation and relative importance of gene effects for yield. Can. J. Plant Sci. 42, 339.

Haj, H. M., Mohamed, H. A. and Eltohami, I. E. (2007) Effects of sowing date and irrigation interval on growth and yield of wheat (Triticum aestivum L.) and its thermal time requirements under new Halfa environment. Journal of Science and Technology, 8, 1.

Hamam, K.A. (2013) Estimation of genetic parameters using five populations model in three bread wheat crosses under normal irrigation and drought stress. $8^{\text {th }}$ International Plant Breeding International Conference, Kafr El Sheikh University, Egypt, $14^{\text {th }}-15^{\text {th }}$ May, 2013.

Hayman, B.I. (1958) The separation of epistatic from additive and dominance variation in generation means. Hereditay, 12, 371.

Hayman, B.I. and Mather, K. (1955) The description of genetic interaction in continuous variation. Biometrics, 11, 69.

Hendawy, H.I. (2003) Genetic architecture of yield and it components and some other agronomic traits in bread wheat. Minufiya J. Agric. Res. 28, 71.

Hu, H.Z. and Rajaram, S. (1994) Differential responses of bread characters to high temperature. Euphytica, 51, 183-189.

Jinks, J.L. and Jones, R.M. (1958) Estimation of the components of heterosis. Genetics, 43, 223. 
Khaled, M.A.I. (2007) Estimation of genetic variance for yield and yield components in two bread wheat (Triticum aestivum L.) crosses. J. Agric. Sci. Mansoura Univ.32, 8043.

Khan, M. I., Tila, M., Fazle, S., Muhamad, A. and Shah, Y.S. (2007) Agronomic evaluation of different bread stress. Pak. J. Bot. 39, 2415.

Maloo, S.R., Sharma, P.C. and Sharma, S.N. (1993) A note on variability in wheat. $J$. Res. (BAU) 5, 83.

Mather, K. (1949) “Biometrical Genetics”. $1^{\text {st }}$ ed., p. 162. Metheum and Co., London.

Olivares-Villegas, J.J., Reynolds, M.P. and McDonald, G.K. (2007) Droughtadaptive attributes in the Seri/Babax hexaploid wheat population. Funct. Plant Biol. 34,189.

Peter, F.C. and Frey, K.J. (1966) Genotypic correlation, dominance and heritability of quantitative characters in oats. Crop Sci. 6, 259.

Rahman M. A. and Saad, M.S. (2000) Estimation of additive, dominance and digenic epistatic interaction effects for certain yield characters in Vigna sesquipedalis Fruw. Euphytica, 114, 61.

Rane, J. and Nagarajan, S. (2004) High temperature index for field evaluation of heat tolerance in wheat varieties. Agricultural Systems, 79, 243-255.

Rebetzke, G.J., Condon, A.G., Richards, R.A. and Farquhar, G.D. (2003) Genetic control of leaf conductance in three wheat crosses. Aust. J. Agric. Res. 54, 381-387.

Reynolds, M.P., Ortiz-Monasterio, J.I. and McNab, A. (2001) Application of physiology in wheat breeding. CIMMYT Mexico. pp, 124-135.

Saint Pierre, C., Crossa, J., Manes, Y. and Reynolds, M. P. (2010) Gene action of canopy temperature in bread wheat under diverse environments. Theor. Appl. Genet.120, 1107.

Sharma, S.N., Sain, R.S. and Sharma, R.K. (2003) Genetics of spike length in durum wheat. Euphytica, 130, 155.

Talebi, R. and Fayyaz, F. (2012) Estimation of heritability and genetic parameters associated with agronomic traits of bread wheat (Triticum aestivum L.) under two constructing water regimes. Journal of Applied Biological Sciences, 6, 35.

Wahid, A., Gelani, S., Ashraf, M. and Floolad, M.R. (2007) Heat tolerance in plant: An overview. Exp. Bot. 61, 199-223.

Yadav, H.K and Singh, S.P. (2011) Inheritance of quantitative traits in opium poppy (Papaver Somniferum L.). Genetika, 43, 113. 
Yap, T.C. (1993) Genetic studies and improvement of long bean in Malaysia. In: Proceedings of the $4^{\text {th }}$ International SABRAO Congress. Crop improvement Research Bangi Malaysia, pp. 95-302.

(Received 3/4/2014 accepted 4/8/2014)

$$
\begin{aligned}
& \text { التحليل الوراني لبعض الصفات المحصولية فى قمح الخبز باستخدام }
\end{aligned}
$$

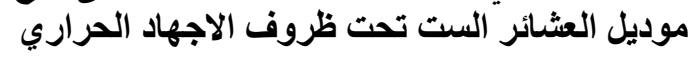

$$
\begin{aligned}
& \text { خلـف على همام } \\
& \text { قسم المحاصيل - كلية الزر اعة - جامعة سو هاج - سو هاج - مصر. }
\end{aligned}
$$

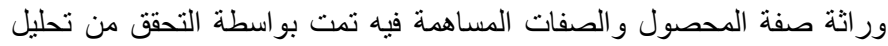

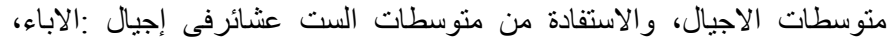

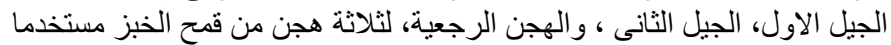

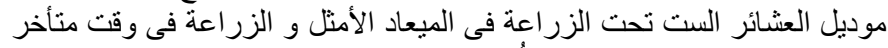

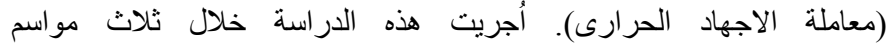

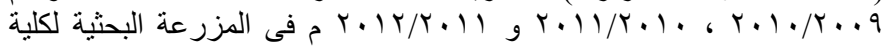

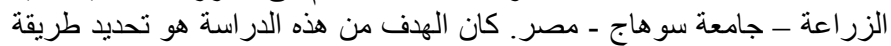

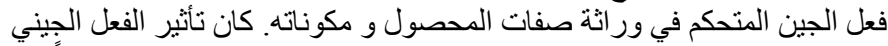

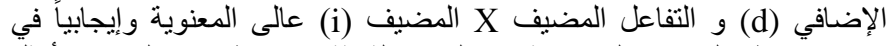

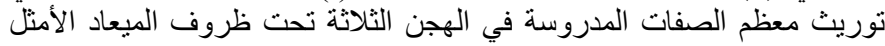

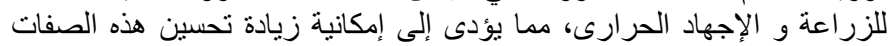

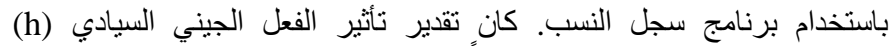

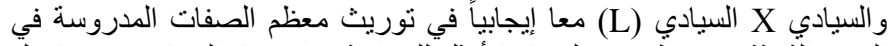

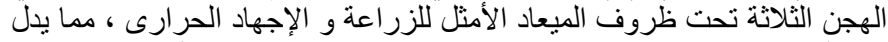

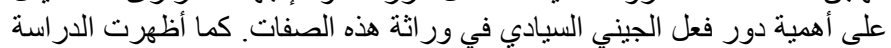

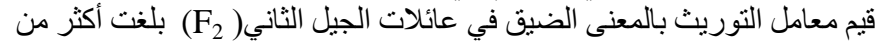

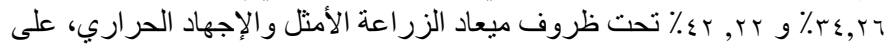

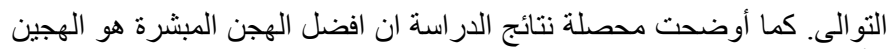

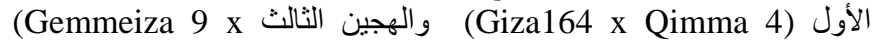
(Johara14)

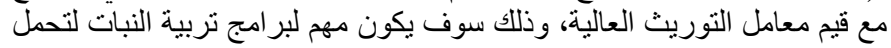

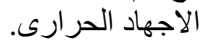

